\title{
ОРГАНИЗАТОРСКАЯ И ПЕДАГОГИЧЕСКАЯ ДЕЯТЕЛЬНОСТЬ НИКОЛАЯ ВИКТОРОВИЧА БОРЗОВА В ХАРБИНЕ
}

\author{
О. А. Косинова \\ Московский гуманитарный университет
}

Аннотация: В статье представлены основные направления деятельности организатора русского педагогического зарубежья Н. В. Борзова (26.04.1871 25.11.1955). В них отчетливо проявляются традиции и новации русской педагогической мысли конца XIX - первой четверти XX вв. Выявляются значимые педагогические идеи образовательного пространства русского зарубежья в Китае.

Ключевые слова: история педагогики; Китай, русское зарубежье; Николай Викторович Борзов; Харбин; биография

\section{ORGANIZATIONAL AND PEDAGOGICAL ACTIVITY OF NIKOLAI VIKTOROVICH BORZOV IN HARBIN}

\author{
O. A. Kosinova \\ Moscow University for the Humanities
}

\begin{abstract}
Аннотация: The article presents the main activities of the organizer of the Russian pedagogical expatriate community N. V. Borzov (26.04.1871 - 25.11.1955). They clearly show the traditions and innovations of Russian pedagogical thought of the late XIX - the first quarter of the XX centuries. Significant pedagogical ideas of the educational space of the Russian expatriate community in China are revealed.

Ключевые слова: history of pedagogy; China; Russian expatriate community; Nikolay Viktorovich Borzov; Harbin; biography
\end{abstract}

Полнота и всесторонность исторического познания в рамках интерпретативного подхода к научному познанию дополняется исследованиями событий прошлого на основе их индивидуального осмысления. Личностная интерпретация событий представляет собой конструкт, соответствующий определенному уровню организации мышления (Шюц, 2004). Поэтому изучение прошлого как продукта человеческой деятельности обуславливает включение материалов биографического характера в круг исторических источников.

С начала 1990-х годов изучение биографий педагогов было выделено в самостоятельный объект исследований истории педагогики и образования. 
В отечественной историографии закрепился обобщенный вывод о том, что жизнь и профессиональная деятельность выдающихся педагогов, наряду с их трудами, являются отражением типичных для своего времени явлений педагогической реальности и, поэтому, данный материал может привлекаться к обоснованию научных фактов (Егоров, 2007: 6-39). Как отмечает В. А. Ситаров, «...ценности, проникая в личность, продолжают свой ход в культуре, а человек как носитель ценностей остается в истории, преодолевая смерть и продолжая жить в социальной памяти» (Ситаров, 2018: 50).

Культурно-образовательное пространство «Русского Рассеяния» (русского зарубежья) на территории Китая показало способность эмиграции к утверждению и обогащению российских педагогических традиций, связанных, прежде всего, с воспроизводством отечественной системы образования. В «портретной галерее» педагогов данного региона выделяется личность начальника учебного отдела Правления Дороги, директора харбинских коммерческих училищ, преподавателя русской словесности Николая Викторовича Борзова (26.04.1871 - 25.11.1955).

Соратники с теплотой и восхищением отзывались о Борзове, отмечая, что его работа внесла существенные результаты в создание и поддержание русского зарубежного образования; первый историограф русской эмиграции П. Е. Ковалевский написал о нем некролог. Между тем, в энциклопедиях и справочных изданиях, посвященных российской пореволюционной эмиграции, его биография отсутствует.

Николай Викторович Борзов родился 26 апреля (по старому стилю) 1871 г. в г. Глазове Глазовского уезда Российской империи. Православный, происходил из потомственных дворян, но поместьем не обладал, закончил историко-филологический факультет Санкт-Петербургского университета с дипломом первой степени. К моменту приглашения переехать в Харбин он уже имел опыт педагогической и организаторской работы. Проработав в Министерстве просвещения два года, Борзов уехал в Сибирь, где до 1903 г. трудился преподавателем русского языка и словесности Томской Мариинской женской гимназии. В этом же году ему был присвоен чин надворного советника. Затем Николай Викторович перешел в Томское коммерческое училище, а в 1904 г. был назначен инспектором этого училища. Он создал также в городе вечернюю школу и участвовал в работе обществ, ставивших своей целью развитие образования в исправительных учреждениях Томска и в деревнях Томской губернии. Благодаря совмещению преподавания с административной и общественной работой Борзов приобрел профессиональный кругозор, заслужил репутацию опытного педагога, пользующегося заслуженными симпатиями как учащихся, так и их родителей (Российский государственный исторический архив, далее - РГИА. Ф. 25. Д. 505. ЛЛ. 3-3об.). 
Научные труды Московского гуманитарного университета 2018 № 4

Впоследствии в Харбине Николай Викторович не только применил приобретенный опыт, но и придал делу образования на Китайско-Восточной железной дороге (КВЖД) должный размах и результативность. Борзов получил приглашение в Харбин сразу на две должности - начальника учебного отдела Правления КВЖД и директора будущего коммерческого училища. К этому моменту он уже был главой большой и крепкой семьи. Всего у Николая Викторовича и его жены Софии Александровны было шестеро детей: три дочери и три сына.

Н. В. Борзов приступил к обязанностям начальника учебного отдела с 20 ноября 1905 г. В это время в крае было примерно 15 школ различных типов и видов, в которых обучалось около 2000 детей: 1269 человек - дети служащих дороги, остальные - дети горожан. Администрация КВЖД обоснованно полагала, что вместе с увеличением протяженности железнодорожного полотна будет расти российское население края и его культурно-образовательные потребности. Правление Дороги ходатайствовало об открытии учебного отдела, и в 1906 г. Министерством народного просвещения было принято беспрецедентное решение - признать право региона на организацию своих органов управления образованием. По сути, на КВЖД был образован отдельный учебный округ с центром в Харбине.

В этом же году в Харбине были открыты сначала мужское, потом женское коммерческие училища - первые русские учреждения профессионального образования в городе. В ситуации быстро растущего российского населения полосы отчуждения перед Николаем Викторовичем встали задачи: увеличения количества учебных заведений КВЖД, прежде всего, начальных училищ, привлечения педагогов, оборудования и учебно-методического оснащения школ. Поэтому преимущественно открывались одноклассные училища со сроком обучения 3-4 года, дававшие начальное образование. За период 1909-1911 гг. их доля в общем количестве школ составила около двух третей. Были учреждены также двухклассные училища с пяти- или шестилетним сроком обучения. Постепенно в крае начали возникать учреждения среднего образования - гимназии и реальные училища. Администрация КВЖД и учебный отдел, в частности, заботились о своих работниках. Высокие зарплаты, обеспеченность жильем и дровами, другие льготы, соответствующие статусу государственных служащих, привлекали отечественных педагогов в этот далекий край. В начале XX века Харбин стал крупным обра-зовательным центром, жители которого имели все условия для получения общего среднего образования, а также для профессиональной подготовки в мужском и женском коммерческих училищах.

Дальнейшие инициативы учебного отдела показали стремление Н. В. Борзова обеспечить себя информацией о состоянии школьного дела. 
Начальник учебного отдела ввел практику отчетов об учебно-воспитательной работе школ. Первый отчет охватывал период с 1898 по 1908 гг.; коммерческие училища издавали отдельные отчеты. В настоящее время они являются ценным историко-педагогическим источником, поскольку содержат статистику по количеству школ, преподавателей и учащихся в них; формируют представление о пространственном росте школ по линии дороги; дают возможность проследить динамику школьного дела по типам, видам учебных заведений и ряду других параметров. Значимость этих документов определяется не только их содержанием, но также и тем, что, будучи опубликованы, они побудили отечественных педагогов края высказывать свою точку зрения по тем или иным проблемам образования, благодаря чему увеличилось общее количество аналитических материалов по педагогической тематике.

Этнокультурные особенности региона повлияли на содержание педагогической деятельности наших соотечественников. На рубеже XIX-XX вв. в Российской империи, стремившейся к освоению своих дальневосточных территорий, на правительственном уровне была осознана проблема недостатка дипломатических и военных кадров со знанием китайского и японского языков. Особенно остро данная проблема обозначилась после Русско-японской войны. Согласно утвержденному министром торговли и промышленности в 1906 г. уставу Харбинских коммерческих училищ (мужского и женского), было предусмотрено преподавание японского языка и китайской разговорной речи в качестве необязательных предметов для желающих, за особую плату. Однако, в действительности было начато преподавание только китайского языка в мужском училище. Причем, вследствие ходатайства Попечительного Совета Харбинских коммерческих училищ) и с согласия Министерства торговли и промышленности с 1907 г. этот язык был включен в число обязательных предметов. Родительский комитет, ссылаясь на многопредметность программы училища, возбудил ходатайство о признании китайского языка необязательным предметом, с тем, чтобы он преподавался для желающих бесплатно. Для разрешения этого вопроса Николай Викторович специально ездил в Санкт-Петербург с тем, чтобы дать справку Межведомственной комиссии по рассмотрению этого вопроса. Н. В. Борзов показал, что недовольство родителей перегруженностью их детей является преувеличенным и сумел отстоять предмет в учебных планах мужского училища. Ходатайство родителей было признано не подлежащим удовлетворению, и китайский язык был сохранен в качестве обязательного предмета. Курс китайского языка изучался в училище за шесть лет, с 3 до 8 классы, при трех недельных уроках в каждом классе. Занятия велись совместно преподавателем из России - выпускником китайско-маньчжур- 
Научные труды Московского гуманитарного университета 2018 № 4

ского отделения Восточного института и его помощником-китайцем (РГИА. Ф. 560. Д. 1101. Л. 286-288).

Дальнейшие события показали правильность его позиции. Так, в «Кратком обзоре современной организации преподавания восточных языков в русских учебных заведениях за 1910 год» отмечалось: «...о результатах изучения этого языка можно судить по тому факту, что в старших классах (Харбинского мужского коммерческого училища $-O$. K.) ученики уже читают китайские повести и прочитанное передают в форме рассказа на китайском языке» (РГИА. Ф. 560. Д. 1101. ЛЛ. 326-349об.).

В начале 1920-х гг. это направление педагогической работы продолжилось. Учебным отделом под руководством Н. В. Борзова было разработано несколько своевременных образовательных проектов: курсы китайского языка для учащихся высших начальных училищ; классы и школы для детей китайской национальности; курсы русского языка для служащих и рабочих китайской национальности. В смету 1922/1923 учебного года был внесен кредит Правления КВЖД в размере 31564 руб. (ГА РФ. Ф.5785. Д.45. Л.26).

Н. В. Борзов был сторонником объединения российских педагогов края. Этот принцип его работы, скорее всего, был элементом стратегии по привлечению новых педагогических кадров в условиях расширяющейся образовательной деятельности по линии КВЖД. В августе 1914 г. в Харбине открылись первые курсы для учителей железнодорожных училищ и народных учителей. С тех пор курсы по разным общеобразовательным наукам возобновлялись периодически через год. Учебный отдел Правления КВЖД был также инициатором ежегодных летних учительских съездов. Начавшие свою работу в 1907 г., учительские съезды были площадкой для обсуждения общепедагогических и методических проблем российского образования в Северной Маньчжурии. В результате совместной работы учебного отдела и делегатов съезда к сентябрю 1917 г. были подготовлены «Новые временные программы школ Китайской Восточной и Уссурийской железной дорог», учитывавшие актуальные педагогические идеи своего времени.

Н. В. Борзов был одним из организаторов Маньчжурского педагогического общества. Учреждение Общества на учительском съезде в 1910 г. и выпуск журнала «Просветительное дело в Азиатской России» способствовали привлечению российской педагогической общественности края к профессиональному обсуждению, проходившему в стране. Научная проблематика, представленная на страницах журнала, широка и интересна: предметная и концентрическая система преподавания, изучение школьниками культуры Китая, организация летних детских площадок, создание учительских и ученических библиотек и др. Участие Н. В. Борзова в этих проектах в качестве организатора наглядно демонстрирует, насколько широка и многогранна 
была его профессиональная деятельность.

Однако, из дошедших до нас источников ясно, что не все положительно оценивали работу учебного отдела. Более того, были противники учреждения данного отдела и расширения его деятельности. Недовольство исходило со стороны педагогов городских учебных заведений Харбина. Прежде всего, его причина заключалась в ведомственной принадлежности учебных заведений. С учреждением в полосе отчуждения отдельного учебного округа и утверждением права учебного отдела определять образовательную политику работники школ начали терять преимущества, предусмотренные для служащих Министерства народного просвещения. Одним из следствий этой ситуации было лишение преподавателей и административных сотрудников городских учебных заведений права зачисления на государственную службу.

Кроме того, серьезнейшим упреком учебному отделу было обвинение в платном характере образования. Служащие дороги, а также все желающие отдать своих детей в железнодорожные школы, лучше оборудованные и организованные, чем городские, не имели для этой цели надлежащих средств. Правление дороги, в ведении которого был этот вопрос, и учебный отдел, как его представитель в Харбине, отказали родителям в бесплатном начальном образовании их детей на том основании, что железнодорожные начальные школы не имеют никакой связи с учебными заведениями России (имелась ввиду ведомственная подчиненность МНП). Проблема касалась, прежде всего, работников среднего и низшего звена, в том числе, рядовых сотрудников самого́ учебного отдела. Они, работая в крупном коммерческом предприятии, каковым была КВЖД, но получая невысокие зарплаты, не могли себе позволить обучать своих детей в школах дороги. В одной из публикаций того времени читаем: «До текущего учебного года с учащихся в начальных школах, если они дети железнодорожных служащих, бралась плата по три рубля в месяц и по пяти рублей в месяц с детей не железнодорожных служащих. Ясно, что такая высокая плата за право учения была непосильной для мелкой "сошки" железнодорожников, особенно при 2-х, 3-х и более обучающихся детей» (Амурский, 1909: 357; курсив источника. - O. К.).

Упомянутая статья содержит и другие обвинения в адрес учебного отдела и лично Н. В. Борзова: навязанную учителям обязанность собирать с учащихся плату за обучение, что нарушало нормальные педагогические отношения между ними; недостаток учебников и наглядных пособий в школах на отдаленных станциях; стремление начальника учебного отдела решать проблемы единолично, без привлечения педагогической и родительской общественности. За недовольством проявилось противостояние двух систем русского образования в крае - железнодорожной и городской, - находившихся в неравном положении. Очевидно, что Н. В. Борзов связывал 
Научные труды Московского гуманитарного университета 2018 № 4

развитие образования в крае именно с деятельностью железнодорожных учебных заведений. Конфликт прояснил и объективные трудности. Так, деление сферы образования на сегменты разной ведомственной подчиненности противоречило утверждению единого принципа управления образованием, закреплению соответствующих образовательных норм, выработке единой образовательной политики.

Профессиональная деятельность Николая Викторовича включала в себя несколько направлений: управление русским зарубежным образованием по линии дороги, включая организацию учебных заведений; преподавание; общественно-педагогическую работу; педагогическую журналистику. Думается, что такая самоотдача говорит о нем, как о педагогически одаренной, творческой личности, понимающей профессию как дело всей своей жизни и служение обществу.

В 1912 г. Н. В. Борзов принял участие в поездке на Царский гимнастический смотр в Санкт-Петербурге в качестве руководителя группы из 53 учащихся 4-8 классов мужского коммерческого училища. В своей статье, посвященной годовщине этого события, он определил главное направление работы педагогов - патриотическое воспитание подрастающего поколения: «...как приятно должно быть от сознания хорошо исполненного общественного долга, как беззаветно хорошо отдаться и работать для блага общего, для счастья и славы родины?! ...Думается, что теперь на много лет, если не навсегда, обеспечены эти юноши от того растлевающего влияния, какое производит, особенно на молодые организмы, сомнение в своих силах, сомнение в силе и значении своей родины» (Борзов, 1913: 57-58). Определяя идею служения своей стране важнейшим жизненным ориентиром для молодежи, Николай Викторович исходил из своих личных патриотических убеждений.

За двадцать лет работы в Харбине Николай Викторович успел сделать многое: начальник учебного отдела; организатор и руководитель торговой школы, мужского и женского коммерческих училищ; председатель «Комитета по учреждению высшего учебного заведения в Харбине» - учредителя Юридического факультета; один из создателей «Общества вспомоществования учащимся вузов, окончивших средние учебные заведения Харбина» и «Комитета по делам высших и специального типа учебных заведений; один из основателей и организаторов системы подготовки педагогических кадров (летних педагогических курсов), Маньчжурского педагогического общества, инициатор проведения ежегодных съездов учителей железнодорожных школ (1907-1925); один из организаторов отряда скаутов на базе коммерческих училищ. 
После того, как в 1925 г. по требованию советских властей он был уволен со службы, Н. В. Борзов переехал в Беркли (США), где жили его дети. Впоследствии он оказался в Сан-Франциско, где продолжил преподавание русской словесности, а также культурно-просветительскую работу в среде русской эмиграции на территории Соединенных Штатов Америки. Умер в в 1955 г.

Таким образом, в жизни и деятельности Н. В. Борзова можно условно выделить три периода: «российский», «китайский», «американский». Однако, дошедшие до нас исторические источники свидетельствуют, что Николай Викторович считал себя и был российским педагогом. В его профессиональной деятельности в Харбине отразились переломные события истории системы образования русского зарубежья - реформа начального и среднего образования в направлении создания средней общеобразовательной школы, возникновение общественно-педагогического движения и педагогической периодики, налаживание межкультурного диалога россиян с народами Китая. Факты биографии Николая Викторовича свидетельствуют, что охват нескольких направлений работы был характерной чертой его профессиональной позиции, ярким проявлением педагогических и организаторских способностей, которыми он, несомненно, обладал. Сопричастность Н. В. Борзова известным событиям и неординарность его личности позволяют рассматривать его биографию как важный источник для изучения истории русского педагогического зарубежья.

\section{СПИСОК ЛИТЕРАТУРЫ}

Амурский, М. (1909) К десятилетию открытия начальных народных школ на территории Китайской Восточной железной дороги // Железнодо-рожная жизнь на Дальнем Востоке. № 8. С. 356-359.

Борзов, Н. В. (1913) К годовщине поездки группы учащихся Харбинского мужского Коммерческого училища на Высочайший смотр в 1912 г. // Просветительское дело в Азиатской России. № 3. С. 49-59.

Егоров, С. Ф. (2007) Теоретические проблемы дифференциации педагогического знания // Методологические, нравственные, правовые и этнические основания педагогики пореформенной России : сборник научных статей / под ред. С. Ф. Егорова. М. : ИТИП РАО. 166 с. С. 6-39.

Ситаров, В. А. (2018) Ценностные ориентиры в воспитании современной молодежи // Знание. Понимание. Умение. № 1. C. 47-57. DOI: 10.17805/ zрu.2018.1.4

Шюц, А. (2004) Избранное : Мир, светящийся смыслом / пер с нем. и англ. М. : РОССПЭН. 1056 с.

Дата поступления: 14.08.2018 г. 
Косинова Оксана Анатольевна - доктор педагогических наук, доцент, профессор кафедры педагогики и психологии высшей школы Московского гуманитарного университета. Адрес: 111395, Россия, г. Москва, ул. Юности, д. 5. Тел.: +7 (499) 374-78-82. Эл. адрес: ido@mosgu.ru

Kosinova Oksana Anatoljevna, Doctor of Pedagogy, associate professor, professor of the chair of Pedagogical Studies and Psychology of the Higher school, Moscow University for the Humanities. Postal address: 5, Yunosti St., Moscow, Russian Federation, 111395. Tel.: +7 (499) 374-78-82. E-mail: ido@mosgu.ru

\section{Для цитирования:}

Косинова О. А. Организаторская и педагогическая деятельность Николая Викторовича Борзова в Харбине [Электронный ресурс] // Научные труды Московского гуманитарного университета. 2018. № 4. URL: http://journals. mosgu.ru/trudy/article/view/809 (дата обращения: дд.мм.гг.). DOI: 10.17805/ trudy.2018.4.5 